\title{
Vitamin B6
}

National Cancer Institute

\section{Source}

National Cancer Institute. Vitamin B6. NCI Thesaurus. Code C1334.

A group of water-soluble vitamins essential for metabolism and normal physiological functions. B6 vitamins, including pyridoxine, pyridoxal, and pyridoxamine, are converted in vivo to pyridoxal phosphate, a cofactor necessary for the synthesis of amino acids, neurotransmitters, and sphing olipids. More than 100 enzymes involved in protein metabolism require vitamin B6 as a cofactor. Vitamin B6 is essential to red blood cell, nervous system, and immune systems functions and helps maintain normal blood glucose levels. Vitamin B6 is found in a wide variety of foods including cereals, beans, meat, poultry, fish, and some fruits and veg etables. (NCI04) 